\title{
DOSIS PUPUK PHOSPHAT DAN TAKARAN PUPUK KANDANG SAPI PADA PERTUMBUHAN DAN HASIL TANAMAN WIJEN (Sesamum indicum L)
}

\author{
Mohamad Baidowi ${ }^{1)}$ dan Agung Setya Wibowo ${ }^{2)}$
}

1)Mahasiswa Jurusan Agroteknologi Fakultas Pertanian Universitas Islam Balitar, Blitar

2) Dosen Jurusan Agroteknologi Fakultas Pertanian Universitas Islam Balitar, Blitar Jl. Majapahit No.4, Sanan Wetan, Kota Blitar, Jawa Timur 66137

\begin{abstract}
Objective of the study was to know the effect of application of phosphate fertilizer and cow manure on the growth and yield of sesame. The experiment was conducted from February to May 2017 at field Rembang Village, Kesamben district, Blitar Regency. This research is factorial randomized block design consisting two factor with three replication following the treatments of phosphate fertilizer $P 1=100 \mathrm{~kg} \mathrm{ha}-1, P 2=150$ $\mathrm{kg} \mathrm{ha-1,P3=} 200 \mathrm{~kg} \mathrm{ha-1}$ and cow manure dose $O 1=5$ ton ha-1, O2= 7,5 ton ha, S3= 10 ton ha-1 were test. The results showed that there's no interaction between dose of phosphate fertilizer treatments and dose of cow manure treatments. The dose $100 \mathrm{~kg}$ ha-1 of phosphate fertilizer is the best treatment on growth and yield of sesame. The dose 10 ton ha of cow manure is best treatment on growth and yield of sesame.
\end{abstract}

\section{Key Word: Sesame, Phosphate Fertilizer, Cow Manure}

\section{PENDAHULUAN}

Wijen (Sesamum indicum L) merupakan buah yang kaya akan manfaat seperti bijinya dapat digunakan untuk bumbu masak, penghias makanan serta menghasilkan minyak nabati, minyak tersebut dihasilkan dari hasil panen yang pertama yang mempunyai nilai kandungan gizi yang tinggi dan berdampak positif bagi konsumennya sehingga wijen mendapat julukan "The Queen of Oil Seeds Crops" (Budi,L.S. 1994). Selain itu wijen juga merupakan tanaman yang mempunyai potensi cerah dalam agroindutri untuk aneka industri dan minyak makan (Mardjono, et al., 2007).

Produksi nasional wijen pada tahun 2005 hanya sebesar 1.853 ton $(0,06 \%$ dari produksi dunia). Peluang peningkatan produksi wijen nasional masih terbuka yakni berupa areal lahan kering yang mencapai lebih dari $75 \%$ lahan pertanian (Nurheru dan Soenardi, 2004).

Pada tahun 2013 pemerintah mengimpor biji wijen sebesar 2.804 ton dan minyak wijen sebesar 545 ton, serta pada tahun 2014 mengimpor biji wijen sebesar 2.862 ton dan minyak wijen 550 ton guna mencukupi kebutuhan konsumsi wijen yang terus meningkat (Anonim, 2016).

Dalam upaya peningkatan kualitas struktur tanah pemberian pupuk kandang sangat diperlukan karena selain memperbaiki struktur tanah dapat menambah $\mathrm{pH}$ tanah, menambah kapasitas penyimpanan air tanah serta mengurangi kerapatan tanah (Sutedjo, 1989). 
Selain penggunaan pupuk kandang, penggunaan pupuk phospat juga sangat diperlukan untuk memaksimalkan produksi tanaman wijen. Ketersediaan Fosfor di dalam tanah terbatas dan sangat dipengaruhi oleh $\mathrm{pH}$ tanah. Fosfor banyak tersedia pada tanah yang memiliki $\mathrm{pH}$ 5-7. Pergerakan $\mathrm{P}$ di tanah sangat lambat, tidak mudah larut, dan tidak mudah tercuci oleh air (Splittstoesser, 1990). Dalam rangka mempertahankan maupun menambang $\mathrm{P}$ dalam tanah peranan pupuk organik juga menghasilkan asam - asam organik seperti asam sitrat, oksalat, tartat, malat dan asam malonat. Asam ini menghasilkan ion yang akan membentuk senyawa komplek yang sukar larut dengan $\mathrm{Al}$ dan Fe. Dengan demikian diharapkan kosentrasi Al, Fe yang bebas dalam larutan tanah akan berkurang (Nyakpa et al, 1988).

Peran $P$ penting untuk pertumbuhan sel, pembentukan akar halus dan rambut akar, memperkuat jerami agar tanaman tidak mudah rebah, memperbaiki kualitas tanaman, pembentukan bunga, buah, dan biji, serta memperkuat daya tahan terhadap penyakit (Soepardi, 1989). Sehingga diharapkan mampu meningkatkan hasil dari wijen.

\section{METODOLOGI PENELITIAN}

Penelitian ini dilaksanakan di lahan persawahan Desa Rembang Kec. Kesamben Kab. Blitar. Penelitian dilaksanakan pada Bulan February 2017 dan selesai pada Bulan Mei 2017.

Bahan yang digunakan antara lain benih wijen varietas winas 2 , pupuk kandang sapi yang dikeringkan, pupuk phospat (TSP) dengan kandugan phospat 36\%, Insektisida Decis 25 EC, Fungisida Dithane M-45.

Alat yng digunakan antara lain meteran, timbangan digital dengan akurasi 1 gram, cangkul, handsprayer, sabit, tugal, alat tulis.

Penelitian ini dilakukan dengan mengggunakan Rancangan Acak Kelompok Faktorial dengan dua faktor yang diteliti :

1. Dosis pupuk phosphate:

$\mathrm{P}_{1}$ : pupuk $\mathrm{P}$ dosis $100 \mathrm{~kg} \mathrm{ha}^{-1}$

$\mathrm{P}_{2}$ : pupuk $\mathrm{P}$ dosis $150 \mathrm{~kg} \mathrm{ha}^{-1}$

$\mathrm{P}_{3}$ : pupuk $\mathrm{P}$ dosis $200 \mathrm{~kg} \mathrm{ha}^{-1}$

2. Takaran Pupuk Kandang Sapi:

$\mathrm{O}_{1}$ : pupuk kandang 5 ton ha ${ }^{-1}$

$\mathrm{O}_{2}$ : pupuk kandang 7.5 ton ha $^{-1}$

$\mathrm{O}_{3}$ : pupuk kandang 10 ton $\mathrm{ha}^{-1}$

\section{HASIL DAN PEMBAHASAN}

\section{Hasil Tinggi Tanaman}

Hasil analisis ragam diketahui bahwa perlakuan dosis pupuk phosphate dan takaran pupuk kandang sapi tidak terdapat interaksi nyata pada peubah tinggi tanaman umur pengamatan pertama yakni 18 hst sampai pengamatan keenam yakni 48 hst. Perlakuan takaran pupuk kandang sapi berbeda nyata pada peubah tinggi tanaman umur 
18 hst dan 24 hst. Tabel rata-rata tinggi tanaman dengan perlakuan takaran pupuk kandang sapi dapat dilihat pada tabel 1.

Tabel 1. Pengaruh Takaran Pupuk Kandang Sapi (O) Pada Tinggi Tanaman Wijen

\begin{tabular}{ccccccc}
\hline \multirow{2}{*}{ Perlakuan } & \multirow{6}{c}{ Tinggi Tanaman (cm) } \\
& $18 \mathrm{hst}$ & $24 \mathrm{hst}$ & $30 \mathrm{hst}$ & $36 \mathrm{hst}$ & $42 \mathrm{hst}$ & $48 \mathrm{hst}$ \\
\hline & \multicolumn{6}{c}{ Pemberian Pupuk Kandang Sapi } \\
O1 (5 Ton Ha-1) & $7.74 \mathbf{a}$ & $12.31 \mathbf{a}$ & $17.94 \mathbf{a}$ & $31.56 \mathbf{a}$ & $54.61 \mathbf{a}$ & $84.55 \mathbf{a}$ \\
O2 (7.5 Ton $\left.\mathrm{Ha}^{-1}\right)$ & $9.26 \mathbf{a}$ & $14.82 \mathbf{b}$ & $19.17 \mathbf{a}$ & $32.74 \mathbf{a}$ & $57.85 \mathbf{a}$ & $88.19 \mathbf{a}$ \\
O3 $\left(10{\left.\text { Ton } \mathrm{Ha}^{-1}\right)}^{11.09 \mathbf{b}}\right.$ & $16.07 \mathbf{b}$ & $20.39 \mathbf{a}$ & $31.00 \mathbf{a}$ & $52.19 \mathbf{a}$ & $81.67 \mathbf{a}$ \\
\hline
\end{tabular}

Ket : Angka-angka yang diikuti dengan huruf yang sama pada baris dan kolom yang sama tidak berbeda nyata pada uji Duncan $(\alpha=0,05)$.

Dari tabel 1 dapat diketahui bahwa tinggi tanaman terbaik perlakuan takaran pupuk kandang sapi pada umur 18 terdapat pada perlakuan O3 (10 ton/ha) yaitu 11,09 cm yang berbeda nyata dengan perlakuan $\mathrm{O} 1$ (5 ton/ha) yaitu $7,74 \mathrm{~cm}$ dan perlakuan $\mathrm{O} 2(7,5$ ton/ha) yaitu $9,26 \mathrm{~cm}$. tinggi tanaman terbaik umur 24 adalah perlakuan $\mathrm{O} 3$ (10 ton/ha) yaitu $16,07 \mathrm{~cm}$ yang berbeda nyata dengan perlakuan O1 (5 ton/ha) yaitu $12,31 \mathrm{~cm}$ tetapi tidak berbeda nyata dengan perlakuan $\mathrm{O} 2(7,5 \mathrm{ton} / \mathrm{ha})$ yaitu $14,82 \mathrm{~cm}$. Hubungan antara tinggi tanaman wijen umur 18 hst dengan takaran pupuk kandang sapi dapat dilihat pada gambar 1 dan hubungan antara tinggi tanaman wijen umur 24 hst dengan pemberian pupuk kandang sapi dapat dilihat pada gambar 2.

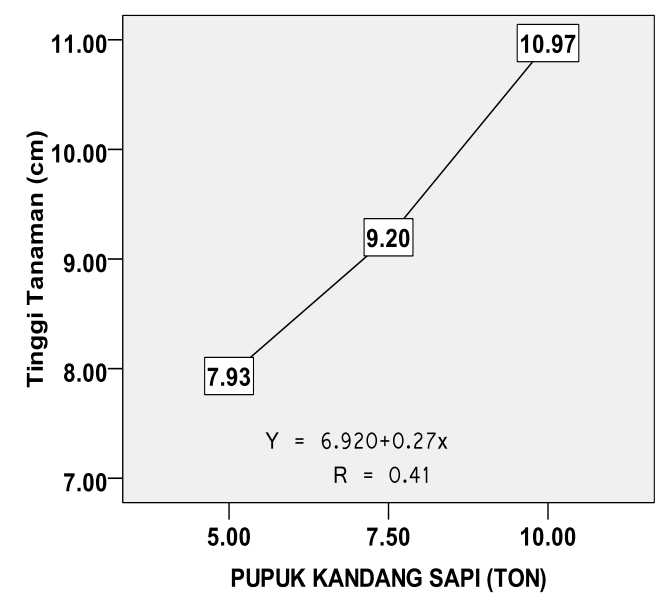

Gambar 1. Hubungan tinggi tanaman wijen umur 18 hst dengan pemberian pukan sapi

Berdasarkan Gambar 1. Dapat dilihat bahwa tinggi tanaman wijen umur 18 hst dengan pemberian pupuk kandang sapi membentuk hubungan linier positif dengan 
membentuk persamaan linier negatif dengan persamaan $\hat{Y}=6,920+0,27 x$ dengan nilai $r$ $=0,41$. Berdasarkan persamaan tersebut dapat diketahui bahwa tinggi tanaman wijen akan semakin cepat seiring dengan peningkatan pemberian pupuk kandang sapi.

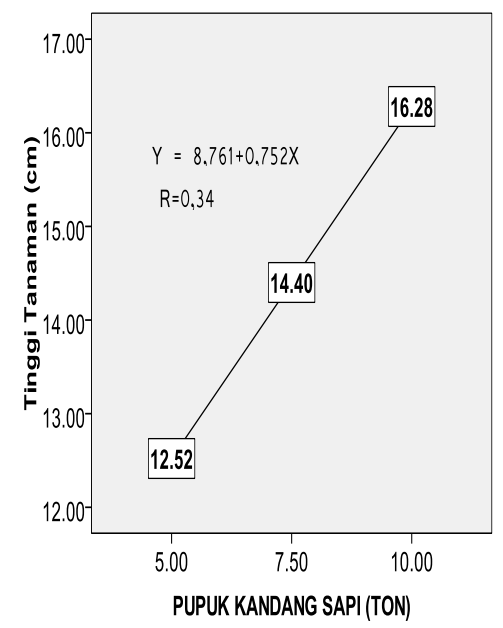

Gambar 2. Hubungan tinggi tanaman wijen umur 24 hst dengan pemberian pukan sapi

Berdasarkan Gambar 2. Dapat dilihat bahwa tinggi tanaman wijen umur 24 hst dengan pemberian pupuk kandang sapi membentuk hubungan linier positif dengan membentuk persamaan linier positif dengan persamaan $\hat{Y}=8,761+0,752 x$ dengan nilai $r$ $=0,34$. Berdasarkan persamaan tersebut dapat diketahui bahwa tinggi tanaman wijen akan semakin cepat seiring dengan peningkatan pemberian pupuk kandang sapi.

\section{Jumlah Polong Pertanaman Saat Panen}

Hasil analisis ragam diketahui bahwa perlakuan dosis pupuk phosphate dan takaran pupuk kandang sapi tidak terdapat interaksi nyata pada peubah jumlah polong pertanaman saat panen. Perlakuan takaran pupuk kandang sapi berbeda nyata pada peubah jumlah polong saat panen. Tabel rata-rata jumlah polong pertanaman saat panen dengan perlakuan takaran pupuk kandang sapi dapat dilihat pada tabel 2.

Tabel 2. Pengaruh Takaran Pupuk Kandang Sapi Pada Jumlah Polong Pertanaman

\begin{tabular}{cc}
\hline Perlakuan & $\begin{array}{c}\text { Jumlah Polong } \\
\text { Pertanaman (buah) }\end{array}$ \\
\hline \multicolumn{2}{c}{ Pupuk Kandang Sapi } \\
O1 & $72.61 \mathbf{a}$ \\
O2 & $79.15 \mathbf{a b}$ \\
O3 & $92.30 \mathrm{~b}$ \\
\hline
\end{tabular}

Keterangan: Angka-angka yang diikuti dengan huruf yang sama pada baris dan kolom yang sama tidak berbeda nyata pada uji Duncan $(\alpha=0,05)$.

Dari tabel 2 dapat diketahui bahwa jumlah polong pertanaman saat panen terbaik perlakuan takaran pupuk kandang sapi adalah perlakuan O3 (10 ton/ha) yaitu 92,30 buah 
yang berbeda nyata dengan perlakuan O1 ( 5 ton/ha) yaitu 72,61 buah tetapi tidak berbeda nyata dengan perlakuan $\mathrm{O} 2$ (7,5 ton/ha) yaitu 79,15 buah. Hubungan antara jumlah polong pertanaman saat panen dengan takaran pupuk kandang sapi dapat dilihat pada gambar 3.

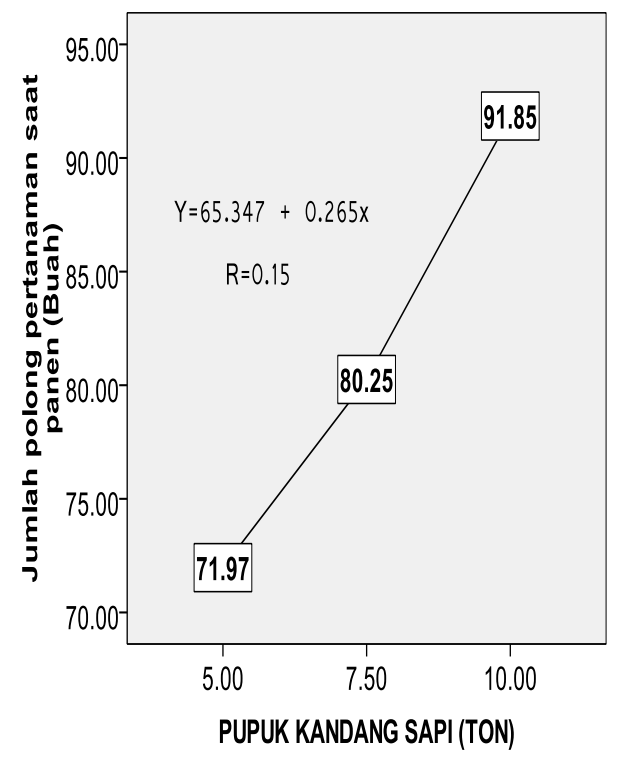

Gambar 3. Hubungan jumlah polong wijen pertanaman saat panen dengan pemberian pukan sapi

Berdasarkan Gambar 3. Dapat dilihat bahwa jumlah polong pertanaman saat panen dengan pemberian pupuk kandang sapi membentuk hubungan linier positif dengan membentuk persamaan linier positif dengan persamaan $\hat{Y}=65,374+0,265 x$ dengan nilai $\mathrm{r}=0,15$. Berdasarkan persamaan tersebut dapat diketahui bahwa jumlah polong akan semakin meningkat seiring dengan peningkatan pemberian pupuk kandang sapi

\section{Bobot Basah Polong Pertanaman}

Hasil analisis ragam diketahui bahwa perlakuan dosis pupuk phosphate dan takaran pupuk kandang sapi tidak terdapat interaksi nyata pada peubah bobot polong basah pertanaman saat panen.

\section{Bobot kering polong pertanaman}

Hasil analisis ragam diketahui bahwa perlakuan dosis pupuk phosphate dan takaran pupuk kandang sapi tidak terdapat interaksi nyata pada peubah bobot polong kering pertanaman saat panen. Perlakuan takaran pupuk kandang sapi berbeda nyata pada peubah bobot polong kering pertanaman. Tabel rata-rata jumlah polong pertanaman saat panen dengan perlakuan takaran pupuk kandang sapi dapat dilihat pada tabel 3 . 
Tabel 3.Pengaruh Takaran Pupuk Kandang Sapi Pada Bobot Polong Kering Pertanaman

\begin{tabular}{cr}
\hline Perlakuan & $\begin{array}{c}\text { Bobot Polong Kering } \\
\text { (Gram) }\end{array}$ \\
\hline \multicolumn{2}{c}{ Pupuk Kandang Sapi } \\
O1 & $33.93 \mathrm{a}$ \\
$\mathrm{O} 2$ & $34.78 \mathrm{a}$ \\
$\mathrm{O} 3$ & $45.52 \mathrm{~b}$ \\
\hline
\end{tabular}

Ket : Angka-angka yang diikuti dengan huruf yang sama pada baris dan kolom yang sama tidak berbeda nyata pada uji Duncan $(\alpha=0,05)$.

Dari tabel 3 dapat diketahui bahwa bobot polong kering terbaik perlakuan takaran pupuk kandang sapi terdapat pada perlakuan O3 (10 ton/ha) yaitu 45,52 gram yang berbeda nyata dengan perlakuan $\mathrm{O} 1$ ( $5 \mathrm{ton} / \mathrm{ha}$ ) yaitu 33,93 gram dan perlakuan $\mathrm{O} 2$ (7,5 ton/ha) yaitu 34,78 gram pertanaman. Hubungan antara bobot polong kering pertanaman saat panen dengan takaran pupuk kandang sapi dapat dilihat pada gambar 4 .

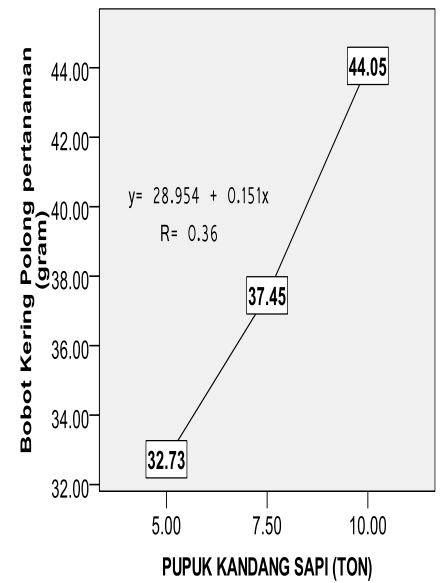

Gambar 4. Hubungan bobot kering polong pertanaman saat panen dengan pemberian pukan sapi

Berdasarkan Gambar 4 Dapat dilihat bahwa bobot kering polong pertanaman saat panen dengan pemberian pupuk kandang sapi membentuk hubungan linier positif dengan membentuk persamaan linier positif dengan persamaan $y=28.954+0.151 x$ dengan nilai $r$ $=0,36$. Berdasarkan persamaan tersebut dapat diketahui bahwa bobot kering polong pertanaman akan semakin bertamabah seiring dengan peningkatan pemberian pupuk kandang sapi. 


\section{Bobot Biji Wijen Kering}

Hasil analisis ragam diketahui bahwa perlakuan dosis pupuk phosphate dan takaran pupuk kandang sapi tidak terdapat interaksi nyata pada peubah bobot biji wijen kering. Hubungan antara bobot biji wijen kering pertanaman dengan takaran pupuk kandang sapi dapat dilihat pada gambar 5.

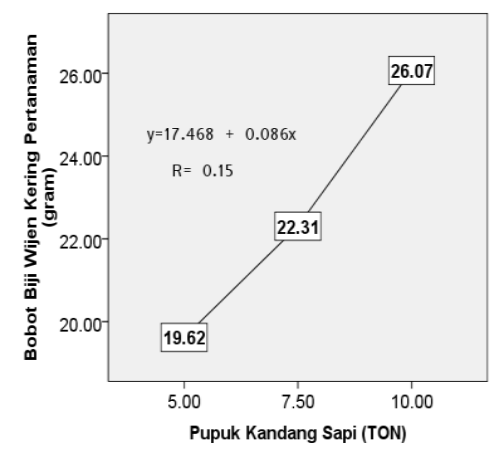

Gambar 5. Hubungan bobot biji wijen kering pertanaman dengan pemberian pukan sapi

Berdasarkan Gambar 5 dapat dilihat bahwa bobot biji wijen kering pertanaman dengan pemberian pupuk kandang sapi membentuk hubungan linier positif dengan membentuk persamaan linier positif dengan persamaan $y=17.468+0.086 x$ dengan nilai $r$ $=0,15$. Berdasarkan persamaan tersebut dapat diketahui bahwa bobot biji wijen kering akan semakin meningkat seiring dengan peningkatan pemberian pupuk kandang sapi.

\section{Tinggi Tanaman}

Perlakuan dosis pupuk phosphate tidak memberikan perbedaan yang nyata pada peubah tinggi tanaman semua umur pengamatan hal ini di duga karena pupuk phosphat merupakan pupuk immobile yang artinya tidak dapat langsung terserap langsung oleh tanaman. mobilitas ion-ion fosfat sangat rendah karena retensinya dalam tanah sangat tinggi. Oleh karena itu kemampuan fosfor menjadi bentuk yang tersedia bagi tanaman yang berasal dari pertambahan pupuk P sangat rendah, yakni antara 10-30\%. Sisanya 7090\% tertinggal dalam bentuk tak larut atau hilang karena erosi (Leiwakabessy dan Sutandi, 2004).

Perlakuan takaran pupuk kandang sapi terdapat perbedaan nyata pada umur 18 hst dan 24 hst. Hal ini diduga pemberian pupuk kandang sapi memperbaiki struktur tanah dan memperbaiki kemampuan tanah dalam menyimpan air sehingga memberikan unsure hara yang dibutuhkan tersedia pada awal pertumbuhan tanaman budidaya. Menurut goenadi (2004) pupuk kandang sapi dapat memperbaiki struktur tanah sehingga aerasi di dalam tanah semakin baik, dan juga dapat memperbaiki kemampuan tanah menyimpan air. Secara kimia, pupuk kandang sapi dapat meningkatkan kapasitas tukar kation sehingga hara yang terdapat dalam tanah mudah tersedia, mencegah hilangnya hara akibat proses pencucian, dan mengandung hormon pertumbuhan yang dapat memacu pertumbuhan tanaman. 


\section{Jumlah Polong Pertanaman Saat panen}

Perlakuan dosis pupuk phosphate tidak memberikan perbedaan yang nyata pada peubah tinggi tanaman semua umur pengamatan hal ini di duga karena pupuk phosphat merupakan pupuk immobile yang artinya tidak dapat langsung terserap langsung oleh tanaman. mobilitas ion-ion fosfat sangat rendah karena retensinya dalam tanah sangat tinggi. Oleh karena itu kemampuan fosfor menjadi bentuk yang tersedia bagi tanaman yang berasal dari pertambahan pupuk P sangat rendah, yakni antara 10-30\%. Sisanya 7090\% tertinggal dalam bentuk tak larut atau hilang karena erosi (Leiwakabessy dan Sutandi, 2004).

Perlakuan takaran pupuk kandang sapi terdapat perbedaan nyata pada peubah jumlah polong saat panen. Hal ini diduga pemberian pupuk kandang sapi meningkatkan kadar $\mathrm{P}$ total dan $\mathrm{P}$ tersedia dalam tanah yang dibutuhkan tanaman saat masa pembentukan organ generative. pemupukan berupa 10 ton/ha pupuk kandang dan $100 \%$ NPK yang diperkaya dengan biofertilizer Azospirillium dan Phosfobakteria @ 2 kg/ha, memberikan hasil yang nyata terhadap jumlah polong, hasil biji, dan memberikan hasil tertinggi 1,11 ton /ha atau 32,\% lebih tinggi dari pada dengan NPK rekomendasi saja, sehingga merupakan suplai nutrisi yang efisien untuk meningkatkan hasil wijen sekaligus perbaikan kesuburan tanah/ soil health (Palaniappan, 2003).

\section{Bobot Kering Polong Pertanaman}

Perlakuan dosis pupuk phosphate tidak memberikan perbedaan yang nyata pada peubah tinggi tanaman semua umur pengamatan hal ini di duga karena pupuk phosphat merupakan pupuk immobile yang artinya tidak dapat langsung terserap langsung oleh tanaman. mobilitas ion-ion fosfat sangat rendah karena retensinya dalam tanah sangat tinggi. Oleh karena itu kemampuan fosfor menjadi bentuk yang tersedia bagi tanaman yang berasal dari pertambahan pupuk P sangat rendah, yakni antara 10-30\%. Sisanya 7090\% tertinggal dalam bentuk tak larut atau hilang karena erosi (Leiwakabessy dan Sutandi 2004).

Perlakuan takaran pupuk kandang sapi terdapat perbedaan nyata pada peubah bobot kering polong saat panen. Hal ini diduga pemberian pupuk kandang sapi menambah $\mathrm{P}$ tersedia di tanah yang berfungsi meningkatkan bobot polong kering saat panen. Agung dan Rahayu (2014) berpendapat bahwa penamambahan pupuk organic menyuplai sebagian unsur hara yang dibutuhkan tanaman dapat dilakukan oleh mikroorganisme yang mempunyai kemampuan menambat $\mathrm{N}$ dari udara dan pelarut fosfat yang dapat merubah unsur $\mathrm{P}$ di dalam tanah menjadi P-tersedia bagi pertumbuhan tanaman.

\section{Bobot Biji Wijen Kering}

Perlakuan dosis pupuk phosphate tidak memberikan perbedaan yang nyata pada peubah tinggi tanaman semua umur pengamatan hal ini di duga karena pupuk phosphat merupakan pupuk immobile yang artinya tidak dapat langsung terserap langsung oleh tanaman. Mobilitas ion-ion fosfat sangat rendah karena retensinya dalam tanah sangat tinggi. Oleh karena itu kemampuan fosfor menjadi bentuk yang tersedia bagi tanaman 
yang berasal dari pertambahan pupuk P sangat rendah, yakni antara 10-30\%. Sisanya 70$90 \%$ tertinggal dalam bentuk tak larut atau hilang karena erosi (Leiwakabessy dan Sutandi, 2004).

Perlakuan pemberian pupuk kandang sapi tidak terdapat perbedaan nyata pada peubah bobot biji wijen kering. Hal ini diduga unsure hara yang tersedia dalam tanah belum terserap secara maksimal ketika pembentukan biji wijen. Hasil penelitian Sutriadi et al (2005) bahwa aplikasi pupuk kandang sebesar 2 Ton/Ha meningkatkan produksi jagung 6\% pada musim pertama sedangkan pada musim kedua sebesar $40 \%$ pada perlakuan tanpa dan dengan bahan organic, peningkatan antar musim mencapai enam setengah kali.

\section{Kesimpulan}

Berdasarkan penelitian yang telah dilakukan dapat ditarik kesimpulan sebagai berikut:

1. Tinggi tanaman terbaik perlakuan takaran pupuk kandang sapi pada umur 18 terdapat pada perlakuan O3 (10 ton/ha) yaitu 11,09

2. Jumlah polong pertanaman saat panen terbaik perlakuan takaran pupuk kandang sapi adalah perlakuan O3 (10 ton/ha) yaitu 92,30 buah yang berbeda nyata dengan perlakuan O1 (5 ton/ha) yaitu 72,61 buah tetapi tidak berbeda nyata dengan perlakuan $\mathrm{O} 2$ (7,5 ton/ha) yaitu 79,15 buah.

\section{DAFTAR PUSTAKA}

Agung, T. dan Rahayu A.T. 2004. Analisis efisiensi serapan N, pertumbuhan dan hasil kedelai unggul dengan cekaman kekeringan dan pemberian pupuk hayati. Jurnal agrisains 6 (2): $70-74$.

Anonim.2016a. http://jatim.bps.go.id/wijen . diakses pada 26 desember 2016

Goenadi., D.H., 2006. Pupuk dan Teknologi Pemupukan Berbasis Hayati. Dari Cawan Petri ke Lahan Petani. Yayasan John Hi-Tech. Idetama., Jakarta. P 29-75.

Leiwakebasy, F.M. dan Sutandi, A. 2004. Pupuk Dan Pemupukan. IPB. Bogor.

Mardjono, R., H. Sudarmo, M. Romli dan Tukimin. 2007. Teknologi Budidaya Dan Pasca Panen Tanaman Untuk Meningkatkan Produksi Dan Mutu Wijen. Prosiding seminar memacu pengembangan wijen untuk mendukung agroindustri 2007. Balai penelitian dan pengembangan pertanian. Bogor.

Nurheru dan sunardi. 2004. Peranan Wijen Dalam Meningkatkan Pendapatan Petani Di Wilayah Kering. Prosiding lokakarya pengembangan jarak dan wijen dalam rangka otoda. P $28-34$. 
Nyakpa M. Y., A. M. Lubis, M. A. Pulung, G.Amrah, A. Munawar, G.B. Hong, dan N. Hakim. 1988. Kesuburan Tanah. BandarLampung. Universitas Bandar Lampung. P 45-78.

Pallaniapan, S.P., A. Jeyabal dan S. Chelliet. 2003. Evaluator Of Integrated Nutrients Management In Summer Sesame (Sesamum indicum L). naga arjuna agricultural research and development institute CIS, Vikrom puri secunderabad - 500 009, India.

Soepardi, G. 1983. Sifat Dan Ciri Tanah saduran dari The Nature And Propertieis Of Soil karangan buckman dan N.C. Brady. 591 hal.

Sutedjo, Ir. Mul mulyani. 1989.Pupuk Dan Cara Pemupukan. Rineka jaya. Jakarta. Pp 47-102.

Sutriadi, M.R., R. Hidayat, S. Royati dan D. Setyorini. 2005. Ameliorasi Lahan Dengan Fosfat Lahan Untuk Perbaikan Kesuburan Tanah KeringMasam Typic Hapludox di Kalimantan Selatan. Hal 143-155. Dalam Prosiding Seminar Nasional Teknologi Sumber Daya Tanah dan Iklim. Bogor 14-15 September 2004. 